\title{
Anti-C1q autoantibodies are linked to autoimmune thyroid disorders in pregnant women.
}

